\title{
PROXIMATE, MINERALS AND ANTINUTRIENT ASSESSMENT OF THE LEAVES AND TENDERSTEM OF Leptadenia hastata (PERS.) DECNE
}

\author{
${ }^{1 *}$ Tijjani Habibu, ${ }^{2}$ Joel B. Enoch, ${ }^{3}$ Ibrahim A. Agiteh, ${ }^{4}$ Abdulai I. Suliat and ${ }^{5}$ Habila Susinya \\ ${ }^{1}$ Natural Products Research Laboratory, Department of Biochemistry, Bauchi State University, Gadau, Nigeria \\ ${ }^{2}$ Department of Biochemistry, Faculty of Medical Sciences, University of Jos, Jos, Nigeria \\ ${ }^{3}$ Biochemistry Unit, Department of Science Laboratory and Technology, Federal Polytechnic Nasarawa, Nasarawa, \\ Nigeria \\ ${ }^{4}$ Department of Biochemistry, Faculty of Life Sciences, University of Ilorin, Ilorin, Nigeria \\ ${ }^{5}$ Department of Plant Science and Technology, Faculty of Natural Sciences, University of Jos, Jos, Nigeria \\ ${ }^{*}$ Corresponding Author: haatscific@gmail.com; +2348037327138
}

\begin{abstract}
The study evaluated the proximate, minerals and antinutrient contents of the plant Leptadenia hastata (Pers.) decne (Asclepiadaceae). Nutrient and antinutritional factors were determined using standard analytical methods and parameters subjected to statistical analysis. Manganese (Mn), Calcium (Ca) and Cobalt (Co) were found to be significantly $(p<0.001)$ higher in the leaves when compared to the tender stem while Iron (Fe), Zinc (Zn) and Magnesium (Mg) were found to be significantly $(p<0.001)$ higher in the tender stems when compared to the leaves. The percentages of Moisture content, Crude proteins and Total ash were found to be significant/y $(p<0.05)$ higher in the leaves when compared to the tender stem while crude fiber and Nitrogen Free Extract (NFE) was significantly $(p<0.05)$ higher in the stem when compared to the leaves. Oxalate and phytic acid were anti nutrient found to be significantly $(p<0.001)$ higher in the leaves when compared to the tender stem. However, Copper (Cu), Lead (Pb), Potassium (K) and Crude fat were not significantly ( $p>0.05)$ different when compared in the leaves and tender stem. Correlation analysis indicated that antinutrient contents in the tender stems will not affect the mineral absorption in the leaves while negative correlation between Fe and $\mathrm{Cu}$ in the stems could affect the absorption of iron. Therefore, Leptadenia hastata leave and tender stem consumed in soup and local salad in northern Nigeria proved to be rich in minerals and nutrients to support its dietary role as a consumed vegetable.

Keywords: Leptadenia hastata, Minerals, Proximate, Antinutrients, Tender stems, Leaves
\end{abstract}

\section{INTRODUCTION}

Leptadenia hastata (Pers.) decne (Asclepiadaceae) is edible, non-domesticated vegetable, which is collected in wild throughout Africa. L. hastata is a valuable herb which grows with a creeping latex stems, glabescent leaves and flowers with follicle fruits. L. hastata is among the few vegetables present in almost all seasons, on dry lands and in sandy soil. Through this it provides food security. The plant is medicinally important in the treatment of many ailments such as catarrh, skin diseases, diabetes, hypertension and it's an active antimicrobial and anti-inflammatory plant (Aliero et al., 2001; Aliero and Wara, 2009; Belloet al., 2011; Dambatta and Aliyu, 2011;Thomas, 2012). The plant is also considered relatively safe, however, it possesses antiandrogenic properties (Bayala et al., 2011). L. hastata is commonly used as a vegetable and is considered as a famine food due to its high content of valuable nutrients (Freiberger et al., 1998; Sena et al., 1998). In Nigeria, the plant is commonly consumed by the Hausa speaking communities as a spice and a sauce (Ibrahim et al., 2012). However, during preparation the leaves and stem are not carefully separated before processing of food. Thus, the present study was aimed at evaluating the proximate, minerals and antinutrient composition of the leaves and, especially, the tender stems of Leptadenia hastata (Pers.) decne.

\section{MATERIALS AND METHODS}

Collection and Preparation

Leptadenia hastata plant was collected from the Bauchi State University, Gadau Campus, Gadau, Bauchi State, Nigeria. The plant was identified in the Herbarium Section, Federal College of Forestry, Jos, Nigeria and sample deposited with a voucher number $\mathrm{FHJ120}$. The plant sample was air dried for 2 weeks under shade. The dry leaves and stem were ground separately into fine powder using pestle and mortar and stored in an airtight container before analysis.

\section{Proximate Analyses}

Moisture

The moisture content was determined using the method of Association of Official Analytical Chemists (AOAC, 2000). The sample was oven dried until constant weight was obtained. The percentage moisture contents for the leaves and stem was determined by subtracting the ratio of the weight of the dried sample over the shade dried weight from 1 and multiplying by 100 . 


\section{Crude Protein}

The total nitrogen content of the samples was determined using the method of $\mathrm{Ng}$ et al.(2008). To convert the nitrogen content to protein, a conversion factor of 4.4 was used.

\section{Crude Fat and Fibre}

Crude fat and fiber were determined using the organic residue left over after a sequential extraction of samples with ether. The fat was extracted first using petroleum ether, followed by stirring, and then allowed to settle and then decanted. The fat free material was preheated with $1.25 \% \quad \mathrm{H}_{2} \mathrm{SO}_{4}$. The sample were made neutral by washing with boiling water, followed by addition of pre-heated $1.25 \%$ $\mathrm{Na}_{2} \mathrm{SO}_{4}$. The residues was completely dried by heating, cooled in a desiccator and weighed. \% Crude fibre was then estimated by multiplying the differences in weight by 100 .

\section{Ash Content}

The leaves and the tender stem were incinerated in a furnace at temperature of $550^{\circ} \mathrm{C}$. The remaining inorganic material was cooled, weighed. Ash solution was prepared by dissolving the ash in $100 \mathrm{~mL}$ of $1 \mathrm{M}$ $\mathrm{HCl}$.

\section{Nitrogen Free Extract (NFE)}

Nitrogen Free Extract (NFE) was determined by subtracting the sum of percentages of all the nutrients already determined from 100 . This included crude protein, crude fiber, ether extract, ash and moisture contents. This value represents the soluble carbohydrates and other digestible and easily utilizable non-nitrogenous substances.

\section{Mineral Analyses}

The leaves and tender stem were carefully weighed. The powdered samples $(10 \mathrm{~g})$ were digested separately in a conical flask with $10 \mathrm{mls}$ of concentrated $\mathrm{HNO}_{3}$ each and $3 \mathrm{mls}$ of $\mathrm{HClO}_{4}$ was added, and heated on a hot plate for one hour. Each sample was filtered and the residue treated with $0.2 \% \mathrm{v} / \mathrm{v} \quad \mathrm{HNO}_{3}$. $4 \mathrm{mls}$ of $\mathrm{HClO}_{4}$ and $2 \mathrm{mls}$ of concentrated $\mathrm{H}_{2} \mathrm{SO}_{4}$ was then added and the mixture heated in an aluminium block digester until white fume evolved and a clear solution obtained. The clear solution was subsequently diluted with appropriate volume of water and stored until required for analysis on an Atomic Absorption Spectrophotometer (AAS650, Double Beam-Shimadzu, Japan).

\section{Calcium Determination}

Calcium was determined from the digested samples using the method of Vogel (1983). A standard solutions and sample solutions were aspirated and absorbance read. The concentrations of calcium in the samples were obtained by extrapolation from the standard calibration plot.

\section{Phosphorous Determination}

Phosphorous was determined based on the formation of phosphomolybdenum blue complexes. The Phosphorous content was complex with acidified ammonium molybdate to form phosphomolybdate, which was then reduced to molybdenum blue by the addition of stannous chloride reducing reagent. The solutions were then read spectrophotometrically at $840 \mathrm{~nm}$ and phosphorous was calculated using the absorbance and a standard curve prepared from different concentrations of potassium dihydrogen phosphate $\left(\mathrm{KH}_{2} \mathrm{PO}_{4}\right)$.

\section{Antinutrient Analysis}

\section{Oxalate}

The oxalate content was determined by first heating approximately $2.0 \mathrm{~g}$ of powdered samples of the leaves and tender stem separately in distilled water and adding $0.3 \mathrm{M} \mathrm{HCl}$ to the samples. The sample was filtered and treated with 2 drops of methyl red indicator and $\mathrm{NH}_{4} \mathrm{OH}$ solution before heating the mixture at a temperature between 90 to $100^{\circ} \mathrm{C} .10$ $\mathrm{cm}^{3}$ of $10 \% \mathrm{CaCl}_{2}$ solution was added to the cooled sample and allowed to stand over for 12 hours. The precipitate formed was filtered, and washed to remove traces of $\mathrm{Ca}^{2+}$ before dissolving in $\mathrm{H}_{2} \mathrm{SO}_{4}$ solution (1:4). The solution formed was brought to near boiling by heating before titrating with $0.05 \mathrm{M}$ $\mathrm{KMnO}_{4}$ solution (AOAC, 1998; Daniel, 2003).

\section{Phytic Acid}

Phytate was extracted from the samples and conversion to ferric phytate, followed by the precipitation of ferric hydroxide from the ferric phytate. Phytic acid was thus calculated from the resulting iron (Ritchie, 1978).

\section{Tannins}

Samples from the leaves and stem were extracted with ethyl acetate using soxhlet apparatus for about 3 hours. The tannin content which appears as the solvent was evaporated and repeatedly washed with petroleum ether $\left(40-60^{\circ} \mathrm{C}\right)$ until no more colour was extracted. The residue was then dissolved in $10 \mathrm{ml}$ ethyl acetate. $5 \mathrm{ml}$ Folin-Denis reagent was added to $5 \mathrm{ml}$ of the tannin extract followed by the addition of $10 \mathrm{ml}$ of saturated sodium carbonate solution. This was diluted to $5 \mathrm{ml}$ with distilled water and left standing for one hour. The absorbance of the resulting blue complex was read at $725 \mathrm{~nm}$ against a blank. This same treatment was given to the standard tannic acid and the concentration of tannin in the sample estimate from a standard curve (Wheeler and Ferrell, 1971).

\section{Statistical Analysis}

The analyses were done in triplicates and data presented as Means and Standard Deviation of Means. The data were analysed using GraphPad InStat Software, version 3.05 (San Diego, California, USA). Pearson Correlation was performed using SPSS Statistics, version 20.0 (IBM Corp., Armonk, N.Y., USA).

\section{RESULTS AND DISCUSSION}

Leptadenia hastate (Pers.) Decne is a wild vegetable commonly used in the Northern Nigeria. The leaves are used as vegetables in the preparation of soup and local salad. Its preparation does not involve a careful selection of the leaves, therefore, sometimes the tender stems are present in the preparation in a little quantity. L. hastata is relayed on as a famine food due to its high content of nutrients (Sena et al., 1998). The leaves and tender stem are also rich in minerals in varying amounts (Figure 1). The plant contains both macrominerals such as magnesium, potassium and microminerals required in a smaller amount than the macrominerals, these include iron, zinc, manganese, cobalt, copper and chromium. 
The presence of copper has been correlated with absorption of iron. Also, copper has been reported as an important cellular defence micromineral (Claude and Paule, 1979), protecting the mucous membrane and essential in the formation of haemoglobin. The substantial amount of iron found in L. hastata indicates that the plant could be a good source of dietary iron to overcome nutritional deficiency ofiron, if supplemented in the diet.

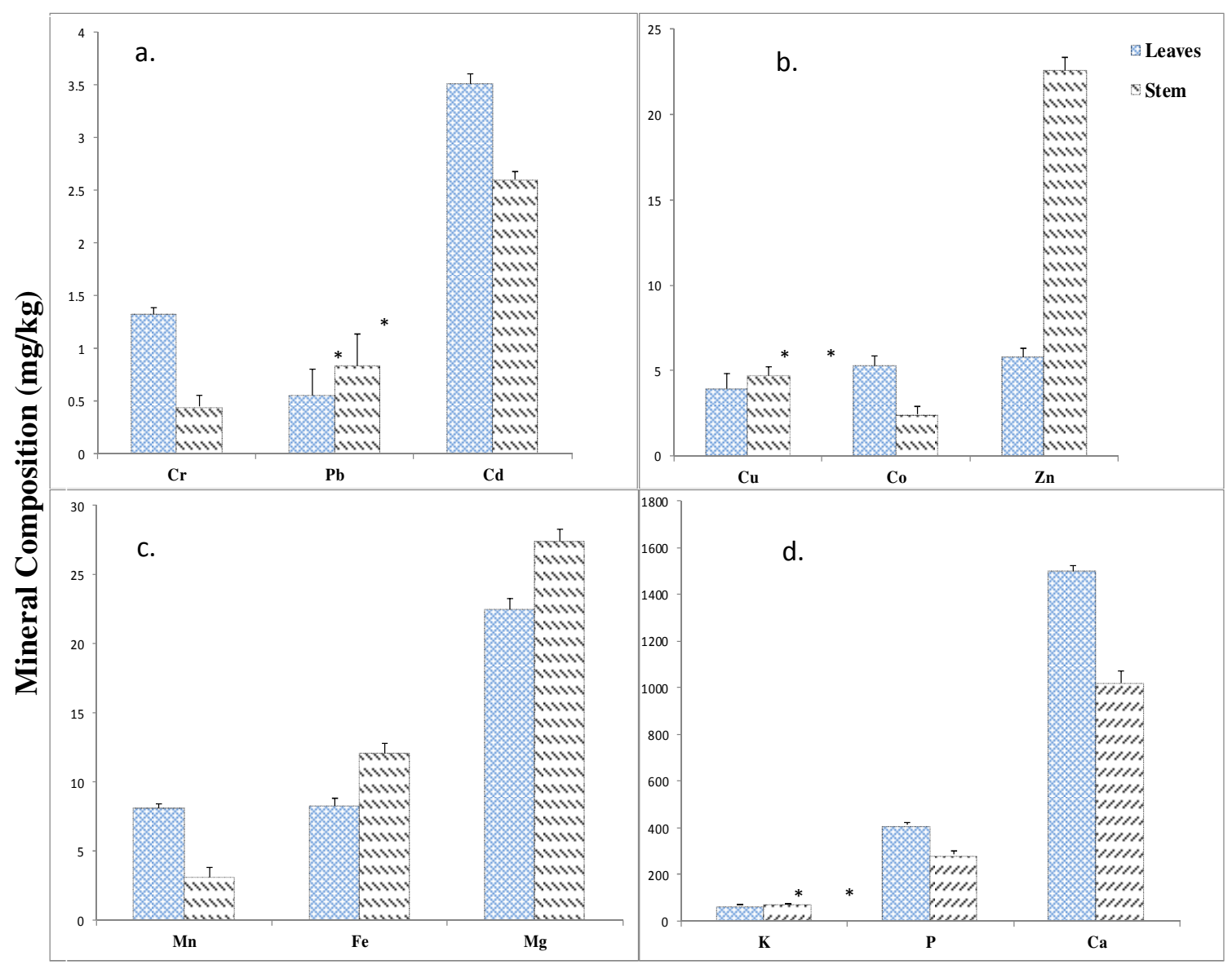

Figure 1: Mineral Composition of the Leaves and Tender Stems of Leptadenia hastata (Pers.) Decne Values are mean \pm SD of triplicate measurement, $*$ No significance $(p>0.05)$

The amount of cobalt and manganese was found to be significantly $(p<0.001)$ higher in the leaves than the stem while magnesium was found to be significantly $(p<0.001)$ higher in tender stem (Figure 1). Manganese has been used in the management of bone diseases (Claude and Paule, 1979). It is required for the functioning of the pituitary gland, pineal gland and the brain. The chromium levels in the leaves of $L$. hastata correlate its use in the treatment of diabetes. Chromium has been linked to diabetes prevention and appears to act by potentiating insulin receptor kinases (Wang et al., 2005). Chromium also plays a part in the glucose tolerance and in cellular responses to insulin. Clinical studies of diabetic patients have shown that chromium can decrease fasting glucose levels, improve glucose tolerance, lower insulin levels and decrease predisposing factors to diabetes by decreasing the total cholesterol and triglyceride levels (Dias, 2012).

Zinc is responsible for a number of biochemical activities in the human body, these include the activation of several enzymes. It also improves the immune system by activation of $T$ lymphocytes (Kaltenberg et al., 2010), hasten wound healing and promote growth during childhood. Zinc has also been found to be useful in healthy functioning of the heart (Elizabeth, 1994). Zinc was found to be significantly $(p<0.001)$ higher in the tender stem when compared with the leaves.

Calcium is required for growth and the maintenance of strong bone and teeth. It is also involved in nerve signalling, muscle contractions and vasodilation (Straub, 2007). Vegetables rich in calcium include onions (Allium cepa), Bitter leaf (Veronia amygdalina) and okra (Ablenioschus esculentus) (Bhattacharjee et al., 2013; Aremu and Ibrahim, 2014). Phosphorous and calcium levels present in the leaves and tender stem of $L$. hastata fall within this range of the minerals, they were however, significantly higher in the leaves at $p<0.01$ and $p<0.001$ when compared with the tender stems respectively (Figure 1). 


\section{BAJOPAS Volume 9 Number 2 December, 2016}

The biological system involves metabolic reactions which involve buffers in the body fluid. Phosphorous is located in the cells of the body, and plays a vital role in maintaining buffered reactions in body fluid (Hays and Swenon, 1985). To assess the safety of the wild plant, we determined the levels of cadmium and lead in the leaves and tender stem. Cadmium is not considered essential for life. It is absorbed from the soil by plants and its accumulation in humans affects human health through bone diseases and kidney damage. Regarding human health, food poisoning by lead and cadmium are the origin of diseases such as autism and neurodegenerative diseases (Alzheimer's, Parkinson's, multiple sclerosis) (Monnet-Tschudi et al., 2006). The quantity of Lead in L. hastata leaves and stem was found to be lesser and within acceptable range $(0.03$ to $5.0 \mathrm{mg} / \mathrm{kg})$ when compared withWHO/FAO permissible limits (WHO/FAO, 2007). However, cadmium was found to be higher in the leaves when compared to the stem and also the values were higher when compared to WHO/FAO permissible limits $(0.1$ to $1.5 \mathrm{mg} / \mathrm{kg})$.
L. hastata contains large amount of crude protein and fiber. The total digestible carbohydrate contents as represented by the NFE were also present in an appreciable quantity (Figure 2). The results indicate that the leaf contains more moisture, crude protein, crude fat and ash contents, but with lower fibre content when compared with the tender stem. Moisture contents of natural products enhance their stability, since high moisture contents tend to promote microbial contamination and chemical degradation (Hussain et al., 2009). Protein content of $L$. hastata is comparable to that of other leafy vegetables, where the protein content ranged from 1 to $7 \%$ of fresh weight or 8 to $30 \%$ of dry weight basis (Uusiku et al., 2010). The ash content is generally recognized as a measure of quality for the assessment of the functional properties of foods (Hofman, 2002). Leptadenia hastata contains high levels of total ash and this, in turn, may indicate a high content of minerals as seen in the mineral profile of the leaf and tender stem.

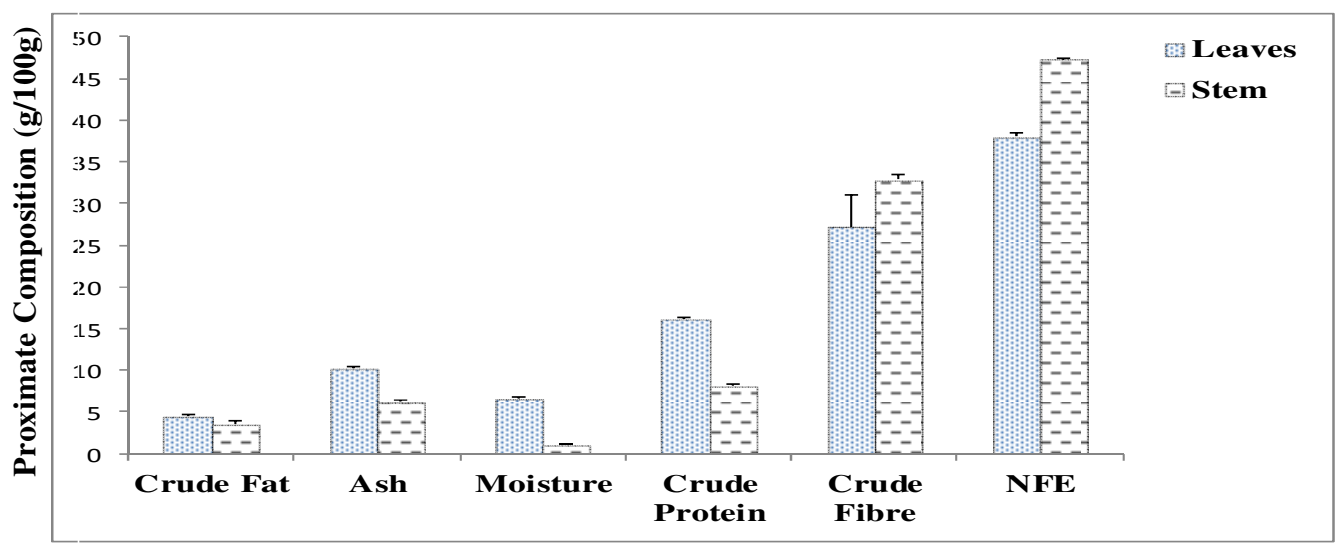

Figure 2: Proximate Composition of the Leaves and tender stems of Leptadenia hastata (Pers.) Decne Values are mean \pm SD of triplicate measurement, $*$ No significance $(p>0.05)$ NFE $=$ Nitrogen Free Extract

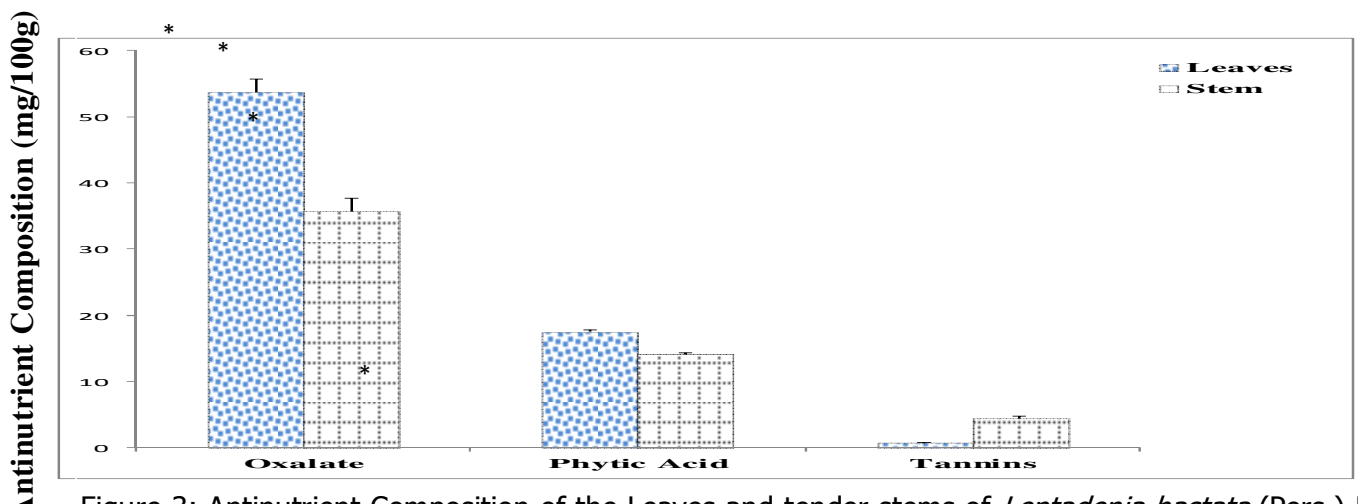

Figure 3: Antinutrient Composition of the Leaves and tender stems of Leptadenia hastata (Pers.) Decne Values are mean \pm SD of triplicate measurement, $*$ Significance $(p<0.001)$

Antinutritional factors are generally toxic and may adversely affect the nutrient content of plants by impairing protein digestibility as well as its mineral availability. The levels of oxalate, phytic acid and tannins are presented in Figure 3. L. hastata contains high levels of oxalate, but moderate values of phytic acid and tannins. The heat labile antinutrient factors may be inactivated by the processing methods of $L$. hastata since it is consumed as a cooked vegetable rather than eating raw. Phytic acid is considered an antinutrient because it forms insoluble complexes with minerals such as iron. Phytate and tannins chelate iron and prevent its uptake during digestion. 
BAJOPAS Volume 9 Number 2 December, 2016

Table 1: Correlation for Mineral Composition of the Leaves and tender stems of Leptadenia hastata (Pers.) Decne

\begin{tabular}{|c|c|c|c|c|c|c|c|c|c|c|c|c|c|c|c|c|c|c|c|c|c|c|c|c|}
\hline & $\mathrm{FeL}$ & $\mathrm{ZnL}$ & $\mathrm{MnL}$ & $\mathrm{MgL}$ & KL & $\mathrm{CoL}$ & $\mathrm{CuL}$ & $\mathrm{CrL}$ & $\mathrm{PbL}$ & $\mathrm{CdL}$ & $\mathrm{CaL}$ & PL & $\mathrm{FeS}$ & $\mathrm{ZnS}$ & MnS & $\mathrm{MgS}$ & KS & $\mathrm{CoS}_{0}$ & $\mathrm{CuS}$ & $\mathrm{CrS}$ & $\mathrm{PbS}$ & $\mathrm{CdS}$ & $\mathrm{CaS}$ & PS \\
\hline FeL & 1 & & & & & & & & & & & & & & & & & & & & & & & \\
\hline $\mathrm{ZnL}$ & 0.942 & 1 & & & & & & & & & & & & & & & & & & & & & & \\
\hline $\mathrm{MnL}$ & $-0.997^{+}$ & -0.915 & 1 & & & & & & & & & & & & & & & & & & & & & \\
\hline $\mathrm{MgL}$ & $1.000^{\circ}$ & 0.935 & $-0.999^{\circ}$ & 1 & & & & & & & & & & & & & & & & & & & & \\
\hline KI & 0.075 & -0.265 & -0.146 & 0.095 & 1 & & & & & & & & & & & & & & & & & & & \\
\hline $\mathrm{CoL}_{0}$ & 0.119 & 0.446 & -0.048 & 0.099 & -0.981 & 1 & & & & & & & & & & & & & & & & & & \\
\hline $\mathrm{CuL}$ & -0.971 & -0.995 & 0.952 & -0.966 & 0.165 & -0.353 & 1 & & & & & & & & & & & & & & & & & \\
\hline $\mathrm{CrL}$ & $1.000^{\circ "}$ & 0.943 & $-0.997^{+}$ & $1.000^{\circ}$ & 0.073 & 0.122 & -0.972 & 1 & & & & & & & & & & & & & & & & \\
\hline $\mathrm{PbL}$ & -0.802 & -0.956 & 0.757 & -0.789 & 0.536 & -0.689 & 0.921 & -0.803 & 1 & & & & & & & & & & & & & & & \\
\hline CdI & 0.942 & $1.000 "$ & -0.915 & 0.935 & -0.265 & 0.446 & -0.995 & 0.943 & -0.956 & 1 & & & & & & & & & & & & & & \\
\hline $\mathrm{CaL}$ & -0.792 & -0.951 & 0.747 & -0.780 & 0.549 & -0.701 & 0.915 & -0.794 & $1.000^{\circ}$ & -0.951 & 1 & & & & & & & & & & & & & \\
\hline PL & $-1.000^{\circ}$ & -0.948 & 0.996 & $-0.999^{*}$ & -0.057 & -0.137 & 0.975 & $-1.000^{\circ}$ & 0.812 & -0.948 & 0.803 & 1 & & & & & & & & & & & & \\
\hline $\mathrm{FeS}$ & -0.527 & -0.211 & 0.586 & -0.544 & -0.887 & 0.781 & 0.309 & -0.525 & -0.085 & -0.211 & -0.101 & 0.512 & 1 & & & & & & & & & & & \\
\hline $\mathrm{ZnS}$ & -0.052 & 0.287 & 0.124 & -0.073 & $-1.000^{\circ}$ & 0.985 & -0.187 & -0.050 & -0.555 & 0.287 & -0.568 & 0.035 & 0.876 & 1 & & & & & & & & & & \\
\hline $\mathrm{MnS}$ & $1.000^{\circ}$ & 0.948 & -0.996 & $0.999^{\circ}$ & 0.057 & 0.137 & -0.975 & $1.000^{\circ *}$ & -0.812 & 0.948 & -0.803 & $-1.000^{\prime \prime}$ & -0.512 & -0.035 & 1 & & & & & & & & & \\
\hline MgS & -0.484 & -0.751 & 0.421 & -0.467 & 0.836 & -0.926 & 0.679 & -0.487 & 0.911 & -0.751 & 0.918 & 0.500 & -0.488 & -0.848 & -0.500 & 1 & & & & & & & & \\
\hline KS & 0.663 & 0.876 & -0.608 & 0.648 & -0.697 & 0.823 & -0.822 & 0.665 & -0.979 & 0.876 & -0.982 & -0.676 & 0.287 & 0.713 & 0.676 & -0.976 & 1 & & & & & & & \\
\hline $\mathrm{CoS}_{0}$ & -0.890 & -0.685 & 0.920 & -0.899 & -0.522 & 0.347 & 0.755 & -0.889 & 0.441 & -0.685 & 0.427 & 0.882 & 0.857 & 0.502 & -0.882 & 0.032 & -0.248 & 1 & & & & & & \\
\hline $\mathrm{CuS}$ & 0.568 & 0.258 & -0.625 & 0.584 & 0.863 & -0.749 & -0.355 & 0.566 & 0.037 & 0.258 & 0.052 & -0.553 & $-0.999^{\circ}$ & -0.852 & 0.553 & 0.445 & -0.240 & -0.881 & 1 & & & & & \\
\hline $\mathrm{CrS}$ & -0.515 & -0.197 & 0.575 & -0.533 & -0.893 & 0.789 & 0.296 & -0.513 & -0.099 & -0.197 & -0.115 & 0.500 & $1.000^{\circ \prime}$ & 0.883 & -0.500 & -0.500 & 0.300 & 0.850 & $-0.998^{*}$ & 1 & & & & \\
\hline $\mathrm{PbS}$ & -0.444 & -0.720 & 0.379 & -0.426 & 0.860 & -0.943 & 0.645 & -0.446 & 0.892 & -0.720 & 0.899 & 0.460 & -0.527 & -0.871 & -0.460 & $0.999^{\circ}$ & -0.965 & -0.013 & 0.485 & -0.539 & 1 & & & \\
\hline CdS & 0.683 & 0.889 & -0.630 & 0.669 & -0.677 & 0.806 & -0.838 & 0.685 & -0.984 & 0.889 & -0.987 & -0.696 & 0.260 & 0.693 & 0.696 & -0.970 & $1.000^{\circ}$ & -0.275 & -0.213 & 0.273 & -0.958 & 1 & & \\
\hline $\mathrm{CaS}$ & 0.953 & 0.795 & -0.972 & 0.959 & 0.374 & -0.188 & -0.853 & 0.952 & -0.582 & 0.795 & -0.569 & -0.947 & -0.760 & -0.353 & 0.947 & -0.196 & 0.404 & -0.986 & 0.791 & -0.751 & -0.151 & 0.429 & 1 & \\
\hline PS & -0.769 & -0.939 & 0.721 & -0.756 & 0.580 & -0.727 & 0.899 & -0.770 & $0.999^{*}$ & -0.939 & $0.999^{\circ}$ & 0.780 & -0.138 & -0.599 & -0.780 & 0.932 & -0.988 & 0.392 & 0.090 & -0.152 & 0.915 & -0.992 & -0.538 & 1 \\
\hline
\end{tabular}

*Correlation is significant at the 0.05 level (2-tailed)

${ }^{* *}$ Correlation is significant at the 0.01 level (2-tailed)

$\mathrm{L}=$ Leaves, $\mathrm{S}=$ Tender Stems 
BAJOPAS Volume 9 Number 2 December, 2016

Table 2: Correlation for Proximate Composition of the Leaves and tender stems of Leptadenia hastata (Pers.) Decne

\begin{tabular}{|c|c|c|c|c|c|c|c|c|c|c|c|c|}
\hline & Mois.L & CPL & CFL & CFaTL & AshL & NFEL & Mois.S & CPS & CFS & CFaTS & AshS & NFES \\
\hline Mois.L & 1 & & & & & & & & & & & \\
\hline CPL & -0.500 & 1 & & & & & & & & & & \\
\hline CFL & 0.541 & $-0.999^{\circ}$ & 1 & & & & & & & & & \\
\hline CFaTL & 0.971 & -0.277 & 0.323 & 1 & & & & & & & & \\
\hline AshI & 0.980 & -0.663 & 0.698 & 0.903 & 1 & & & & & & & \\
\hline NFEL & 0.985 & -0.640 & 0.677 & 0.915 & $1.000^{\circ}$ & 1 & & & & & & \\
\hline Mois.S & 0.945 & -0.756 & 0.787 & 0.839 & 0.991 & 0.987 & 1 & & & & & \\
\hline CPS & -0.524 & $1.000^{\circ}$ & $-1.000^{\circ}$ & -0.304 & -0.683 & -0.661 & -0.774 & 1 & & & & \\
\hline CFS & 0.853 & 0.026 & 0.022 & 0.953 & 0.731 & 0.751 & 0.635 & -0.001 & 1 & & & \\
\hline CFaTS & 0.756 & -0.945 & 0.960 & 0.577 & 0.871 & 0.857 & 0.929 & -0.954 & 0.303 & 1 & & \\
\hline AshS & 0.806 & 0.110 & -0.062 & 0.924 & 0.671 & 0.693 & 0.568 & 0.083 & 0.996 & 0.222 & 1 & \\
\hline NFES & -0.976 & 0.676 & -0.710 & -0.896 & $-1.000^{\circ}$ & $-0.999^{\circ}$ & -0.993 & 0.696 & -0.719 & -0.880 & -0.658 & 1 \\
\hline
\end{tabular}

Mois. $=$ Moisture, $\mathrm{CP}=$ Crude protein, $\mathrm{CF}=$ Crude Fiber, $\mathrm{CFaT}=$ Crude Fat, Ash, NFE $=$ Nitrogen Free Extract, $\mathrm{L}=\mathrm{Leaves}, \mathrm{S}=\mathrm{Tender}$ Stems

Table 3: Correlation for Antinutrient Composition of the Leaves and tender stems of of Leptadenia hastata (Pers.) Decne

\begin{tabular}{lcccccc}
\hline & Oxalate L & Phytate L & Tannin L & Oxalate S & Phytate S & Tannin S \\
\hline Oxalate L & 1 & & & & & \\
Phytate L & 0.609 & 1 & & & & \\
Tannin L & 0.971 & 0.401 & 1 & & & \\
Oxalate S & -0.846 & -0.938 & -0.693 & 1 & & \\
Phytate S & 0.923 & 0.868 & 0.803 & -0.986 & 1 & \\
Tannin S & 0.971 & 0.401 & $1.000^{*-}$ & -0.693 & 0.803 & 1 \\
\hline
\end{tabular}

**Correlation is significant at the 0.01 level (2-tailed)

$\mathrm{L}=$ Leaves, $\mathrm{S}=$ Tender Stems 
In the correlation analysis, $\mathrm{Mn}$ in the leaves indicated a negative correlation with $\mathrm{Fe}, \mathrm{Mg}$, and $\mathrm{Cr}$ in the leaves when compared in a 2 tailed Pearson correlation at $p<0.05$ level (Table 1 ).

A perfect negative correlation $(r=-1.000)$ existed between $\mathrm{P}$ in the leaves, and $\mathrm{Fe}$ and $\mathrm{Cr}$ in leaves and $\mathrm{Mn}$ in the tender stems at $\mathrm{p}<0.05$ and $\mathrm{p}<0.01$ respectively. Also, a perfect positive correlation ( $r=$ 1.000) was seen in $\mathrm{Fe}$ in the leaves when correlated with $\mathrm{Mg}, \mathrm{Cr}$ in leaves and $\mathrm{Mn}$ in tender stems (Table 1 ). For Cadmium and Lead, a perfect positive correlation ( $r$ $=1.000$ ) exists between them and $\mathrm{Zn}$ and $\mathrm{Ca}$ in leaves at $p<0.01$ and $p<0.05$ respectively.

In comparison for proximate and antinutrient contents, No significant $(p>0.01)$ correlation was observed in the oxalate and phytate contents. However, when compared in a 2 tail test, Tannins in the Leaves showed a perfect positive correlation $(r=1.000)$ at $p<0.01$ with tannins in tender stems of $L$. hastata (Table 3 ). The analysis also showed significant correlation $(p<0.05)$ in Crude Fiber and Nitrogen Free Extracts in leaves and tender stems of the plant (Table 2). A perfect $(r=1.000)$ and near perfect $(r=-0.999)$ correlation in the total ash content of the leaves and Nitrogen Free Extracts of Leaves and Nitrogen Free Extracts of the tender stems respectively were observed.

\section{REFERENCES}

A.O.A.C. (1998): Association of Official Analytical Chemists, Official Methods of Analysis. 16th Edition. Washington D.C. USA.

A.O.A.C. (2000): Association of Official Analytical Chemists, Official Methods of Analysis of AOAC International, 17th Ed.; AOAC International: Gaithersburg, MD, USA.

Aliero, A.A. and Wara S.H. (2009): Validating the medicinal potential of Leptadenia hastata.African Journal of Pharmacy and Pharmacology, 3(6):335-338.

Aliero, B.L,. Umar, M.A., Suberu, H.A. and Abubakar, A. (2001): A Hand Book of Common Plant in Northern Western Nigeria. 78.

Aremu, M.O. and Ibrahim, H. (2014): Mineral Content of Some Plant Foods Grown in Nigeria: A Review. Food Science and Quality Management, 29:71-89.

Bayala, B., Pellicer-Rubio, M.T., Bassole, I.H.N., Belemtougri, R., Tamboura, H.H. and Malpaux, B. (2011): Effects of Aqueous Extracts of Leptadenia hastata (Pers.) Decne. (Asclepediaceae) on Male Reproductive Functions Using Castrated Immature Rats. Research Journal of Medicinal Plant, 5:180-188.

Bello, A., Aliero, A.A., Saidu, Y. and Muhammad,S. (2011): Hypoglycaemic and Hypolipidaemic
The above indicates that the antinutrient contents in the tender stems will not affect the mineral absorption in the leaves. The positive correlation between $\mathrm{Fe}, \mathrm{Mg}, \mathrm{Mn}$ and $\mathrm{Cr}$ could be beneficial, while negative correlation between $\mathrm{Fe}$ and $\mathrm{Cu}$ in the tender stems could affect the absorption of iron. $\mathrm{Zn}, \mathrm{Ca} \mathrm{P}$ and $\mathrm{Mg}$ may also be affected due to the presence of $\mathrm{Cd}$ and $\mathrm{Pb}$.

\section{CONCLUSION}

The findings from this study unveil the potentials of the plant Leptadenia hastata as an important source of nutrients. Thus, $L$. hastata can find its usefulness as a potential source of functional foods. Its nutritional values can enhance its already established medicinal properties, as the presence of the tender stem does not negatively affect the nutritional content of the leaves. Effort should be made in assessing the antinutritional contents before and after different methods of food processing, this will allow for an optimal nutritional use of the plant.

\section{CONTRIBUTIONS OF AUTHORS}

All authors contributed equally and gave consents for the publication of the paper.

\section{CONFLICT OF INTEREST}

Authors declare no conflict of interest.

Effects of Leptadenia hastata (Pers.) Decne in Alloxan Induced Diabetic Rats. Nigerian Journal of Basic and Applied Science, 19 (2): 187-192.

Bhattacharjee, S., Sultana, A., Sazzad, M.H., Islam, M.A., Ahtashom, M.M. and Duzzaman, A. (2013): Analysis of the Proximate Composition and Energy Values of Two Varieties of Onion (Allium Cepa L.) Bulbs of Different Origin: A Comparative Study. International Journal of Nutrition and Food Sciences, 2(5):246-253.

Claude, B. and Paule, S. (1979): The Manual of Natural Living. 1st Ed Biddles Limited Guildeford Survey, 101: 98-99.

Dambatta, S.H. and Aliyu, B.S. (2011): A survey of major ethnomedicinal plants of Kano North Nigeria, their knowledge and uses by traditional healers. Bayero Journal of Pure and Applied Sciences, 4:28-34.

Daniel, C.H. (2003): Quantitative Chemical Analysis. Sixth Edition. W. H. Freeman Company, New York.

Dias, J.S. (2012): Nutritional Quality and Health Benefits of Vegetables: A Review. Food and Nutrition Sciences, 3:1354-1374.

Elizabeth, K. (1994): Textbook on immense help from natures workshop, 1st ed., Elikaf Health Services Ltd., 207. 
Freiberger, C.E., Vandergagt, D.J., Pastuszyn, A., Glew, R.S., Mounkarla, G., Millson, M. and Glew, R.H. (1998): Nutrient content of edible leaves of seven wild plants from Niger. Plant Foods. Hum. Nutr., 53(1): 57-69.

Hays, V.W. and Swenson, M.J. (1985): Minerals and bones. In: Dukes' Physiology of Domestic Animals. tenth edition, 449-466.

Hofman, P.J., Vuthapanich, S., Whiley, A.W., Klieber, A. and Simons, D.H. (2002): Tree yield and fruit minerals concentrations influence "Hass" avocado fruit quality. Sci. Hort., 92:113-123.

Hussain, K., Ismail, Z., Sadikun, A. and Ibrahim, P. (2009): Proximate and qualitative analysis of different parts of Piper sarmentosum, and quantification of total amides in various extracts. Phcog. Res.,1:113-119.

Ibrahim, H.A., Ali, G.Y., Halliru, S.N., Usaini, S. and Abdullahi, I.I. (2012): Ethnobotanical Survey of the Wild Edible Food Plants Consumption among Local Communities in Kano State, North-Western, Nigeria. International Journal of Science and Technology, 2:713-717.

Kaltenberg, J., Plum, L.M., Ober-Blöbaum, J.L., Hönscheid, A., Rink, L. and Haase, $H$. (2010): Zinc signals promote IL-2-dependent proliferation of $\mathrm{T}$ cells. Eur.J.Immunol.,40:1496-1503.

Monnet-Tschudi, F., Zurich, M.G., Boschat, C., Corbaz, A. and Honegger, P. (2006): Involvement of environmental mercury and lead in the etiology of neurodegenerative diseases. Rev Environ Health, 21:105-117.

Ng, E.C., Dunford, N.T. and Chenault, K. (2008): Chemical characteristics and volatile profile of genetically modified peanut cultivars. $J$. Biosci. Bioeng., 106:350-356.
Ritchie, J.A.S. (1978): Manual on child development, family life and nutrition. ECA/FAO, United Nations, Addis Ababa.

Sena, L.P., Vanderjagt, D.J., Rivera, C., Tsin, A.T., Muhamada, I., Millson, M., Pastuszyn, A. and Glew, R.H. (1998): Analysis of nutritional component of eight famine foods of the republic of Niger. Plant Foods Hum. Nutr., 52(1):17- 30.

Straub, D.A. (2007): Calcium supplementation in clinical practice: A review of forms, Doses and indications. Nutr. Clin. Pract., 22:286-296.

Thomas, S.D. (2012): Leptadenia hastata: A Review of its Traditional uses and its Pharmacological Activity. Med chem., 2:148-150.

Uusiku, N.P., Oelofse, A., Duodu, K.G., Bester, M.J. and Faber, M. (2010): Nutritional value of leafy vegetables of sub-Saharan Africa and their potential contribution to human health: A review. J. Food Comp. Anal.,23:499-509.

Vogel, A.I. (1983): Quantitative Inorganic Analysis, Fourth Edition . Longman London, 122-125.

Wang, H., Kruszewki, A. and Brautigan, D.L. (2005): Cellular Chromium Activation of Insulin Receptor Kinase. Biochemistry, 44(22):81678175.

Wheeler, E.L. and Ferrell, R.E. (1971): A method for phytic acid determination in wheat and wheat fractions. Cereal Chem., 48:312-320.

WHO/FAO (2007): Joint FAO/WHO Food Standard Programme Codex Alimentarius Commission 13th Session. Report of the Thirty Eight Session of the Codex Committee on Food Hygiene. Houston, USA. 